\title{
OPPORTUNITY OF MOBILE TELEMEDICINE TECHNOLOGY FOR CERVICAL CANCER SCREENING IN DEVELOPING COUNTRIES: A SYSTEMATIC REVIEW
}

\author{
Rizka Arviliana1), Atfiana Nur Afifah"), Tris Eryando²) \\ 1)Masters Program in Public Health, Universitas Indonesia \\ ${ }^{2)}$ Department of Biostatistics, Faculty of Public Health, Universitas Indonesia
}

\begin{abstract}
Background: Cervical cancer is the leading cause of cancer death in females. However, a largescale screening of precancerous lesions with cytology is hardly possible, because of the lack of specialists and infrastructures. Telemedicine describes the use of mobile phone including picture, video, or email to exchange information in the context of health care between patients, providers, consultants, and content for the purpose of education, evaluation, decision-making, and treatment. The purpose of this study was to systematically review the opportunity of mobile telemedicine technology for cervical cancer screening in developing countries.

Subjects and Method: A systematic review was conducted by searching published article from PubMed, Sage Publications, Scopus, and ProQuest online journal databases. The research question was formulated in PICOS format: (1) Population; (2) Intervention; (3) Comparison; (4) Outcome; and (5) Study design. An initial search found 401 articles. 8 articles were met criteria and selected for this study.

Results: Mobile telemedicine is used as a complementary alternative intervention to increase the coverage of early detection of cervical cancer. Visual inspection acetic acid and complemented with digital photography has been used in Rwanda with a significant success. The health workers use a digital camera to capture images of the cervix and share it with remote experts for consultation and further diagnosis. In a different example, the Botswana model involves taking images of the cervix using mobile smartphone and transmitting the images to remote experts through multimedia messaging service (MMS).
\end{abstract}

Conclusion: Mobile telemedicine offers a potential complementary screening method for pre cervical cancer lesion diagnosis.

Keywords: telemedicine, cervical cancer, screening, developing country

\section{Correspondence:}

Rizka Arviliana. Masters Program in Public Health, Universitas Indonesia. Jl. Margonda Raya, Pondok Cina, Beji, Depok 16424. East Jawa. Email: rizkaarviliana74@gmail.com. Mobile: +62 85215143393

\section{BACKGROUND}

Cervical cancer ranks the highest in developing countries, the tenth in developed countries or the fifth worldwide. Cervical cancer is a cancer that occurs among women with estimated 570,000 new cases in 2018 representing $6.6 \%$ of all women's cancer (WHO, 2018). Indonesia cervical cancer ranks the second out of 10 most leading cancers based on the data of Pathological Anatomy 2010 with 12.7\% incidents (Ministry of Health, 2018).

High mortality rate of cervical cancer can be reduced globally through comprehensive approach that covers prevention, effective screening and medication therapy. In all developing countries healthcare for cervical cancer screening are limited by financial factor and access to healthcare facilities (WHO, 2018). World Health Organization recommends Visual Inspection with Acetic Acid (VIA) 
with low cost, easy to do and enable immediate treatment (WHO, 2013).

A study in Mongolia with a sample of 2000 women, shows extremely high compliance toward cervical cancer screening however there were still abnormal diagnosis found (only $5.7 \%$ of them were VIA-positive and pap smear). Therefore, it needs to organize training for health workers (doctors, midwives and nurses) to improve the quality of cervical cancer screening (Elit, 2006). A study by Gravitt (2010) revealed that nurses are less competent in identifying the real positive acetowhite by using VIA that leads to diagnosis discrepancy when it is compared to experts' interpretation by using photographic inspection with acetic acid (PIA) method.

Mobile telemedicine by using cellular phone to take pictures of cervix after VIA examination, allows doctors in cervical cancer screening clinic to observed high quality pictures of cervix, which is then transmitted through cellular network to gynecologists (Gormley, 2010). Mobile telemedicine is potential to help health workers in interpret the result of VIA examination (Quinley, 2011).

In Indonesia itself telemedicine has been used since the 1990s, and nowadays it has been significantly developed. The development of Information and Communication Technologies- based (ICT) application system in Indonesia facilitates even more the real problem faced in improving public healthcare (Santoso, 2015). The utilization of telemedicine in Indonesia among others are teleradiology (using ICT to send digital radiology image), Telepathology (using ICT to send digital pathology result), Teledermatology (using ICT to send medical information about skin condition), and Telepsychiatry (using ICT for psychiatry evaluation or video and phone consultation). However the use of telemedicine for cervical cancer screening is not yet implemented in Indonesia ( $\mathrm{Pa}-$ saribu, 2018). The study aims to review the studies related the use of mobile telemedicine for cervical cancer screening.

\section{SUBJECTS AND METHOD}

\section{Design of the Study}

This was a systematic review using PRISMA (Preferred Reporting Items for Systematic Reviews and Meta-Analyses) followed by PICO-S (population, intervention, compare, outcome, study design) method. Omitting irrelevant articles by using article identification, screening and eligibility.

The steps of the study consisted of identifying research questions, developing protocol of systematic review study, determining database of the study as the area of searching for articles, selecting relevant study results, extracting data, analyzing and reporting the result.

\section{Inclusion and Exclusion Criteria}

Inclusion criteria of the study were: 1) population of the study with articles about healthcare providers, 2) Journal of studies in Developing Countries, 3) Journals, articles, in English and are publish from 1 January 2009 up to September 2019, 4) document availability (free of charge) and 5) documents published in the area of public health and medical science. The exclusion criteria were: other database, the use of language other than English, inaccessible (paid), articles published before 2009, other intervention in the study.

\section{Data Extraction}

The article was prepared from four online 
databases namely: Pubmed, Sage Publications, Scopus, and ProQuest. The search was conducted by using PICO-S method (Population: healthcare providers, Intervention: the use of mobile telemedicine, Comparison: none, outcome: cervical cancer screening). Key words in every database covered smartphone OR telemedicine OR mobile phone AND screening AND developing AND cervical cancer. The filters included being published in the last 10 years and accessible.

Initial search found 401 articles from 4 online databases. After verifying the duplication through Mendeley and manually re-verifying them, there were 394 articles found were free from duplication, further reduction, was conducted by observing the desired file form and complete text format. Therefore there were 8 articles which were found in accordance with the inclusion criteria. To evaluate the selected articles, the writer used Critical Appraisal Skills Programme and Center of Evidence Based Management. Finally, the search obtained 8 articles that were thoroughly reviewed, adjusted with the systematic review as it is presented in Figure 1.

\section{RESULTS}

Our search identified 8 articles originated from some countries. The study was conducted in 7 developing countries namely Madagascar, Brazil, Cape Town South Africa, Korea, Bostwana, India, and Ghana. Based on the design of the studies, the six studies used quantitative study (cross sectional and experimental) and the 2 others used qualitative study. The study indicated that the majority of the articles discussed about the effectiveness of using mobile telemedicine to improve cervical cancer screening.

Large number of women use cellular phone altogether to send and receive short messages, using Whatsapp (an application that use internet to send text messages, images and video) (Moodley, 2019; Shiferaw, 2016).

Considering the vastly utilization of cellular phone (98\%) and smart phone (83\%) among adults, therefore cellular phone-based health intervention becomes a low-cost method to reach populations which are difficult to reach and with limited healthcare access. (Lee, 2014; Grant, 2019). Therefore, the existence of cellular phone based- technology may improve motivation to conduct behaviour related to cervical cancer prevention (Lee, 2019; Moodley, 2019).

The utilization of telemedicine is also supported by Catarino (2015), reported that doctors in facilities that directly carry out VIA have sensitivity of $66.7 \%$ and specificity of $85.7 \%$.

It is identical with the result of long distance VIA diagnosis by doctor with sensitivity of $66.7 \%$ and specificity of $82.3 \%$. The data indicate the similarity between the result of health professionals inside and outside the location, and suggest the use of telemedicine enables supporting healthcare service in remote areas (Quinley, 2011; Taghavi, 2018). 


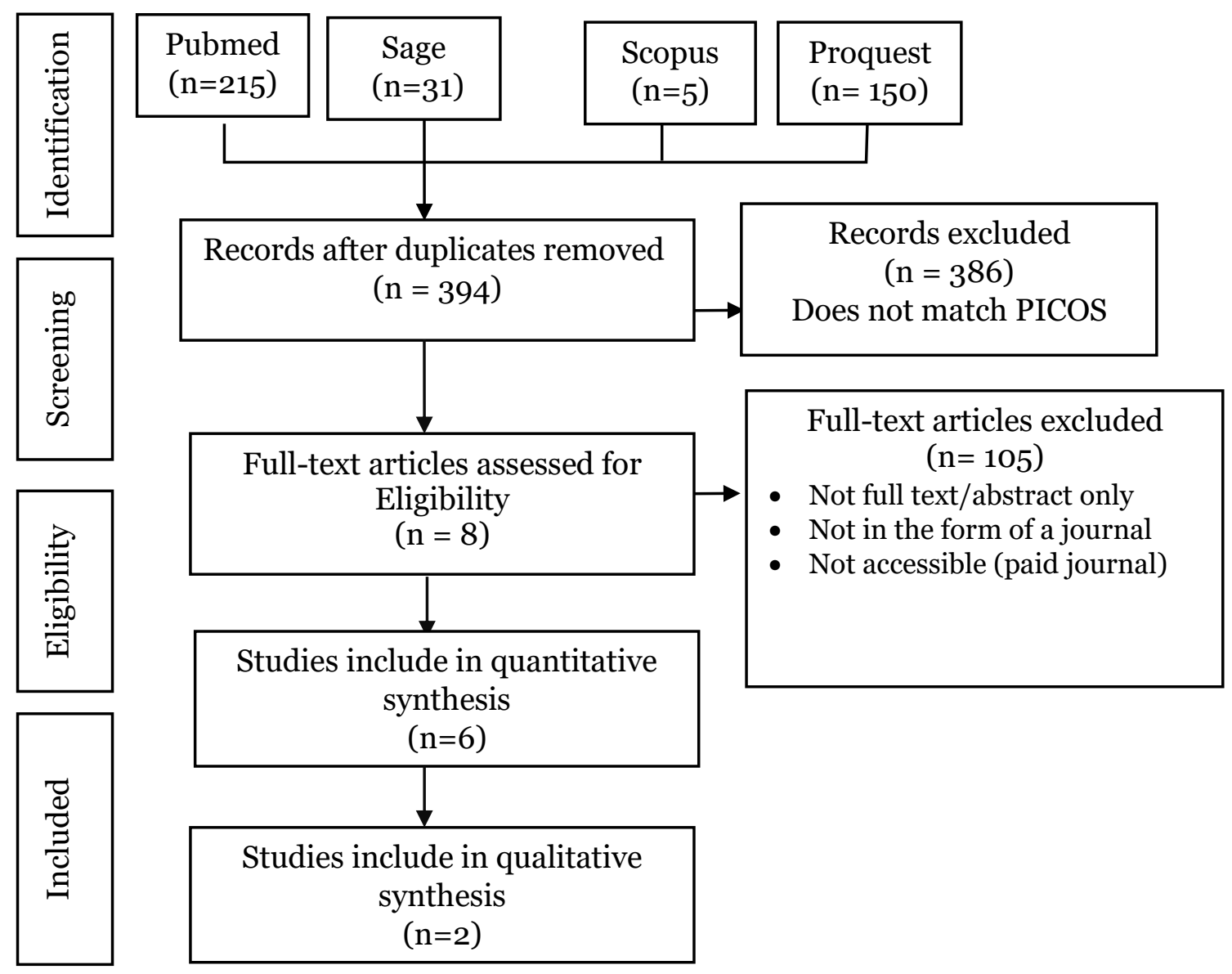

Figure 1. PRISMA Flow Diagram

Table 1. Content Matrix Article Reviewed On Title, Researcher, Year, Country, Sample Size, Result and Conclusion

\begin{tabular}{|c|c|c|c|c|}
\hline No & Title & $\begin{array}{c}\text { Author (Year) } \\
\text { Country/ Sample } \\
\text { Size }\end{array}$ & Result & Conclusion \\
\hline 1. & $\begin{array}{l}\text { Smartphone } \\
\text { Use for } \\
\text { Cervical } \\
\text { Cancer } \\
\text { Screening in } \\
\text { Low-Resource } \\
\text { Countries: A } \\
\text { Pilot Study } \\
\text { Conducted in } \\
\text { Madagascar }\end{array}$ & $\begin{array}{l}\text { Rosa et al. (2015) } \\
\text { Madagascar/ } 332 \\
\text { women }\end{array}$ & $\begin{array}{l}\text { VIA method could be } \\
\text { conducted by non-doctor } \\
\text { primary health workers. To } \\
\text { take decent photos of cervix } \\
\text { by using Samsung Galaxy } \\
\text { S5, there were several } \\
\text { aspects need to consider, it } \\
\text { should consider the } \\
\text { development of procedure } \\
\text { standardization. Since the } \\
\text { most important was taking } \\
\text { good quality pictures of } \\
\text { cervix by VIA providers. }\end{array}$ & $\begin{array}{l}\text { We support the propernes } \\
\text { of telemedicine use for } \\
\text { detecting Cervical-Intra } \\
\text { epithelial Neoplasia and } \\
\text { cancer, with diagnostic } \\
\text { accuracy which is similar } \\
\text { with the result of direct } \\
\text { examination }\end{array}$ \\
\hline 2. & $\begin{array}{l}\text { A mobile- } \\
\text { phone based }\end{array}$ & $\begin{array}{l}\text { Benjamin et al. } \\
\text { (2019) Brazil }\end{array}$ & $\begin{array}{l}\text { Development in cellular } \\
\text { phone technology and rapid }\end{array}$ & $\begin{array}{l}\text { We believe the gadget is } \\
\text { probably to have special }\end{array}$ \\
\hline
\end{tabular}


high-

resolution

micro

endoscope to

image cervical

pre-cancer

3. Exploring the feasibility of using mobile phones to improve the management of clients with cervical cancer precursor lesions

4. Mobile Phone

Text

Messaging

Intervention

for Cervical

Cancer

Screening:

Changes in

Knowledge

and Behavior

Pre-Post

Intervention

5. Use of mobile

telemedicine

for cervical

cancer

screening
Jennifer et al. (2019)

Cape Town, South

Africa/364 women

Lee et al. (2014)

Korean American/

30 women

Quinley et al. (2011)
Botswana/99 women

6. Colposcopy

telemedicine:

live versus

static swede

score and

accuracy in

detecting

CIN2+, a

cross-sectional

Taghavi et al. (2018) India/94 women prototyping techniques

brought about the

opportunity to develop

diagnostic picture taking

techniques. Since the

picture taking by using high

resolution cellular phone

was able to reach cervical

epithelia sub-cellular

The use of mHealth (mobile

health) in communicable

and non-communicable

diseases management

increased with several

proves that short message

intervention might

increased the medication

compliances and improve

the meeting attendance and

support one's behavioural

change

In the visit 1 week post-test,

25 out of 30 participants

(83\%) reported their

satisfaction toward

mScreening (mobile

screening) and 29

participants (97\%) reported

they would recommend

mScreening to their friends.

The study indicated that in

$70 \%$ cases, long distance

diagnosis that used cellular

phone photo entirely was in accordance with the result of VIA conducted directly

The study indicated that the use of static pictures was as good as direct examination in the cervical colposcopy

function in countries where the screening technique is difficult to implement.

The study indicates that mHealth intervention is considered positive by the majority of women.

However, important issues, including confidentiality and privacy as well as integration issue and mHealth intervention management into larger health information system, should be handled to realize the potentials.

The study reveals that cellular technology is a promising tool to improve knowledge about cervical cancer and Pap test acceptance. The study gives proves of properness, acceptance, and satisfaction toward mScreening intervention.

The use of the technique potentially connects cancer screening centers with limited resource with gynecologist who is distantly located to provide screening for women in all over rural of Africa with limited nursing access. Telemedicine offers potential to improve screening to significantly detect cervical pre-cancer lesion in the area where examination with gynecologist is not available. 
pilot study

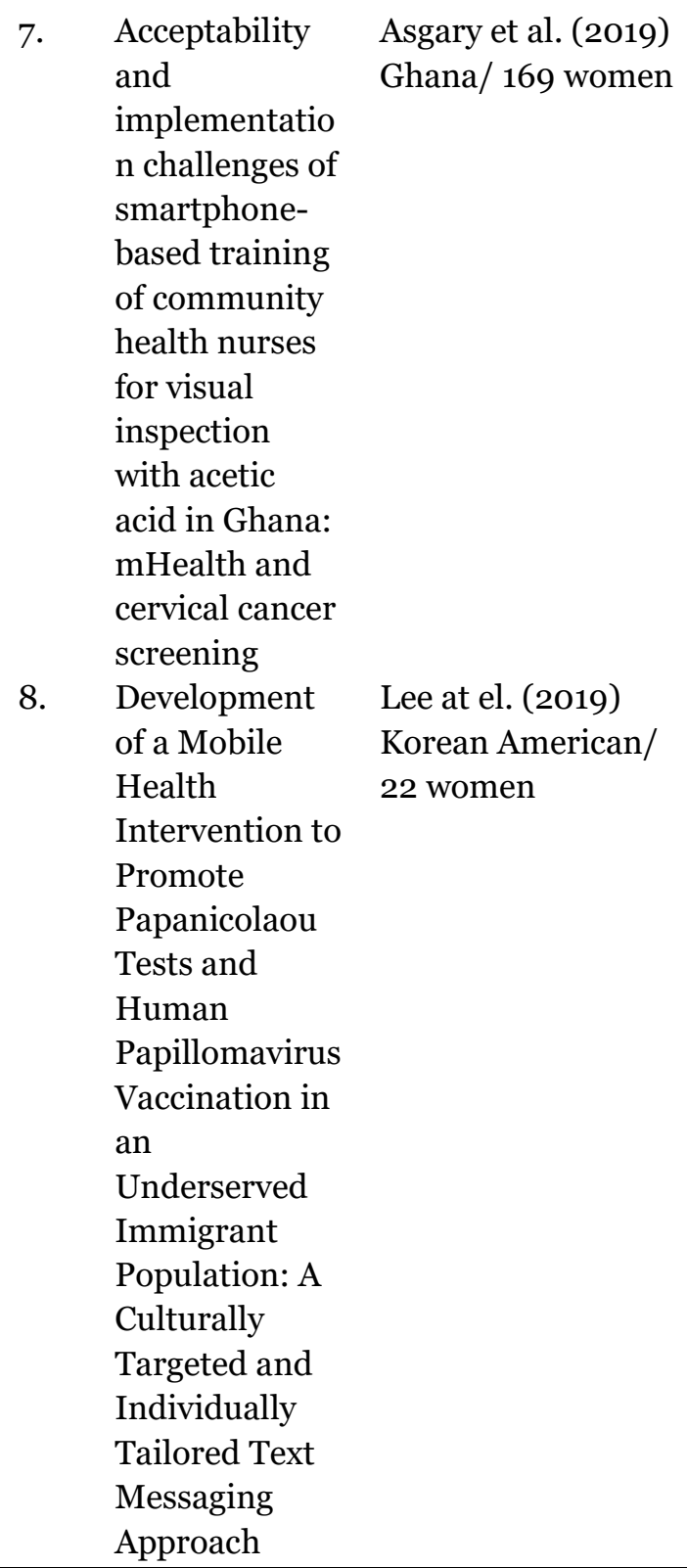

The study indicated the entire acceptance and the feasibility to implement smartphone-based picture taking for VIA and guidance training for health workers for cervical cancer screening. As a whole, there was an important promise to improve the quality and effectiveness of smartphone based VIA screening and its implementation.

Cellular phone did not only turn out to be the most common means of communication among youngsters, but also might become a mHealth technology that had proven its effectiveness as a useful tool for behavioral change in chronic diseases prevention and management. The findings of the study potentially guide the intervention development of cancer screening in the future.
Our finding suggests the entire acceptance toward the approach from the perspective of all stakeholders, with an expectation that it may implement smartphone based VIA.
The development of the intervention should be conducted in cervical cancer screening to promote pap test and HPV vaccination to the underserved minority groups

\section{DISCUSSION}

Information and communication technology hold great potential to overcome problems in developing countries by providing easy to access, cost effective and high quality healthcare (Ryu, 2012; Lee, 2014; Sunjaya, 2019). Some studies reveal that with the existing health intervention through smartphone-based technology it may improve the knowledge and awareness in cervical cancer screening and it saves time that it is not necessary to take a day off from work (Moodley, 2019; Catarino, 2015). 
Previously, during cervical cancer screening, they took picture of VIA by using digital camera and saved the pictures in laptops. The existence of smartphone that can take high quality picture and rapidly send the information holds advantages such as very handy, no need external light source and possible to magnify the photographs easily. Therefore it omits the needs for scientific camera and laptop and significantly reduces the amount of cost and increases portability (Catarino, 2015).

Experience proves that smartphone holds a capacity to monitor subtle alteration of cervix and to introduce simple quality process that may be used to become cervical cancer screening (Catarino, 2015; Grant, 2019). Studi Gauthier (2015) discovered that taking picture of cervix during VIA examination by using smartphone might increase the magnification of cervical epithelium compared to direct diagnosis.

A study by Thagavi (2018) also discovered a positive correlation between telemedicine and the improvement of access to specific nursing, lower down cost for patient and as a whole increases social economy restoration. If long distance diagnosis though VIA examination is organized effectively and safely by using telemedicine, women will be willing to undergo examination. And it will reduce the prevalence of cervical cancer (Quinley, 2011).

Survey of APJII (Association of Internet Service Providers in Indonesia) in October 2016 reported that $132.7 \mathrm{mi}$ llion (51.8\%) of Indonesian citizen has been connected to the internet. Today, Indonesia is the third largest smartphone users in Asia-Pacific. Survey of APJII also reported that penetration of $100 \%$ is discovered among employees in private sector and health sector (Sunjaya, 2019). The technology advance may become the vanguard in health program. Telemedicine technology may turn into one of the solutions in overcoming health problems in Indonesia (Anwar, 2013).

Various examples of e-health applications included in telemedicine among others are: biometric based patients' record and identification, early detection of osteoporosis and osteoarthritis, detection of diabetic retinopathy, cataract tele-diagnosis, tele-dermatology, tele-radiology, and processing software for various supporting functions of diagnosis phase (Santoso 2015. Legowo, 2013). A study by Arjuna (2019) discovered the ratio of medication success of by using mobile health is 1.28 times those without using mobile health. It indicates significant correlation $(\mathrm{OR}=1.28 ; 95 \% \mathrm{CI}=1.21-1.35$; $\mathrm{p}<$ o.001).

According to Arjuna (2019) in Britto (2015), the use of mobile health may increase the compliance toward nursing care plan from $53 \%$ into $94 \%$, reduce expenses, and increase health workers efficiency. Mobile health technology may also conduct rapid diagnosis of preeclampsia $7.21 \%$ faster that manual system, and statistically significant with $\mathrm{p}=0.041$ (Aini, 2019).

Meanwhile in Indonesia, cervical cancer screening is conducted by using Visual Inspection with Acetic Acid (VIA) and pap smear. The result of examination toward women of 25-36 years old in Indonesia is still very low with $3.5 \%$ (1547) for VIA and 7.7\% (3444) for Pap smear.

The number of women who undergo VIA does not yet achieve national target 
which is around $10 \%$ each year. The national target of VIA examination is 50\% on women of 30-50 years old up to 2019 (Ditjen P2PL, 2015).

The high number of cervical cancer patients in Indonesia ideally is balanced with the number of providers, knowledge and skill improvement of health workers (general practitioners, midwives and nurses) is required to be able to perform screening and VIA and pap smear training (Kemenkes, 2015).

Therefore it needs a collaboration between telemedicine technology developers and government for healthcare improvement in Indonesia. Continuous and synergistic collaboration of various parties from variety of disciplines is the main requirement for the success of telemedicine technology utilization in Indonesia as well as in various developing countries (Anwar, 2013; Santoso, 2015; Pasaribu, 2018).

Limitation of the systematic review includes the possibility of technical mistake during article filtering and limited published literatures for the study. However, the references help demonstrate the potential use of telemedicine in improveing cervical cancer screening. With the wide spreading internet network and smartphone connectivity, telemedicine technology offers potential solution in improving access and quality of cervical cancer screening to regions that do not provide examination by gynecologist.

Quality and effectiveness improvement of smartphone based VIA screening and its implementation are needed in developing countries with high cervical cancer prevalence. The opportunity of telemedicine to develop in Indonesia is still wide open, therefore it is time for Indo- nesia to have national certitude concerning with telemedicine to be able to give legal security for health practitioners as well as patients who use telemedicine healthcare.

\section{REFERENCES}

Aini FN, Melyana W, Bedjo S (2019). Diagnosa preeklampsia pada ibu hamil menggunakan sistem informasi berbasis web. Jurnal Keperawatan Silampari (JKS). 2 (2): 18-27. doi: 10.31539/jks.v2i2.508

Anwar (2013). Aspek hukum penggunaan telemedicine. Forum informatika kesehatan Indonesia. Retrieved from http://publikasi.dinus.ac.id/index.p $\mathrm{hp} /$ fiki2013/article/view/525

Arjuna (2019). Mobile health upaya dalam meningkatkan keberhasilan pengobatan pasien tuberculosis. Jurnal ilmiah stikes citra delima Bangka Belitung. 2 (2): 1-7.

Catarino R, Vassilakos P, Scaringella S, Undurraga-Malinverno M, MeyerHamme U, RicardGauthier D, et al. (2015) Smartphone use for cervical cancer screening in low-resource countries: A pilot study conducted in Madagascar. PLoS ONE 10 (7):1-10 doi: 10.1371/journal.pone.0134309

Elit L, MD, G. Baigal, MD, J. Tan, MD, A. Munkhtaivan, MD (2006). Assessment of 2 cervical screening methods in Mongolia: cervical cytology and visual inspection with acetic acid. American Society for Colposcopy and Cervical Pathology. 10 (2): 83-88.

Gauthier Ricard D, Wisniak A, Catarino $\mathrm{R}$, van Rossum AF, Meyer-Hamme $\mathrm{U}$ et al. (2015). Use of smartphones as adjuvant tools for cervical cancer 
screening in low-resource settings. 19(4): 295-300 doi: 10.1-097/LGT.0000000000000136

Grant BD, Quang T, Possati-Resende JC, Scapulatempo-Neto C, de Macedo Matsushita G, Mauad EC, et al. (2019) A mobile-phone based highresolution micro endoscope to image cervical precancer. PLOS ONE 14 (2): 1-12. doi: 10.1371/journal.pone.0211045

Lee HY, Lee MH, Sharratt M, Lee S, Blaes A (2019). Development of a mobile health intervention to promote papanicolaou tests and human papillomavirus vaccination in an underserved immigrant population: a culturally targeted and individually tailored text messaging approach. JMIR mHealth uhealth. 7(6): 1-15 doi: 10$.2196 / 13256$

Legowo N, Prasta J, Winarya C (2013). Model telediagnosis serangan jantung untuk para praktisi kesehatan menggunakan mobile phone. Comtech. 4 (2); 742-750

Ministry of Health (2016) Laporan riset penyakit tidak menular: tumor payudara dan lesi prakanker serviks. Badan Penelitian dan Pengembangan Kesehatan. Retrieved from http://labmandat.litbang.depkes.go.id/riset-badan-litbangkes/menuriskesnas/menu-rikus/424-rptm2016.

Ministry of Health (2018). Pedoman nasional pelayanan kedokteran tata laksana kanker serviks. Retrieved from http://kanker.kemkes.go.id/guidelines/PNPKServiks.pdf

Moodley J, Constant D, Botha $\mathrm{MH}$, van der Merwe FH, Edwards A, Momberg M (2019). Exploring the feasi- bility of using mobile phones to improve the management of clients with cervical cancer precursor lesions. BMC Women's Health 19 (2): 110 doi: 10.1186/s12905-018-0702-1

Pasaribu KF, Arisjulyanto D, Hikmatushaliha BT (2018). Pengembangan telemedicine dalam mengatasi konektivitas dan aksesibilitas pelayanan kesehatan, 34 (11). Retrieved from https://journal.ugm.ac.id/bk$\mathrm{m} /$ article/view/40576

Quinley KE, Gormley RH, Ratcliffe SJ, Shih T, Szep Z, Steiner A et al. (2011). Use of mobile telemedicine for cervical cancer screening. 17 (4): 203-209.

Sunjaya (2019). Potensi, aplikasi dan perkembangan digital health di Indonesia. Journal of the Indonesian medical association. 69 (4): 167-169. Retrieved from http://ojs-mki.idionline.org/index.php/jinma/article/view/265.

Taghavi K, Dipanwita B, Ranajit M, Helena KK, Malin T et al. (2018). Colposcopy telemedicine: live versus static swede score and accuracy in detecting CIN2+, a cross-sectional pilot study. BMC Women's Health. 18 (89). 1-8.

World Health Organization (2013). Who guidelines for screening and treatment of precancerous lesions for cervical cancer prevention. Retrieved from http://apps.who.int/iris/bitstream/10665/94830/1/9789241548694_eng.pdf

World Health Organization. (2018). Cervical cancer. Retrieved from https://www.who.int/cancer/prevention/diagnosis-screening/cervicalcancer/en/. 